\title{
Analogy Supported-Scientific Explanation Text to Improve High School Students' Understanding of The Concept of Heat Transfer
}

\author{
D Nurdiansah ${ }^{1}$, A Suhandi, and R Efendi ${ }^{2}$ \\ Physics Education Program, Sekolah Pascasarjana UPI, Bandung, Indonesia \\ $\left\{{ }^{1}\right.$ nurdiansahdian33@upi.edu $\}$ \\ Physics Education Program, Sekolah Pascasarjana UPI, Bandung, Indonesia
}

\begin{abstract}
Low understanding of concepts is one of the classic problems faced in learning physics in senior high schoolls. This research was conducted to test the use of analogy supported scientific explanatory text (AS-SEText) in learning physics to obtain depiction about its effectiveness in improving senior high school students' conceptual understanding of the heat transfer concepts. Scientific Explanatory text is written in computer format and analogy used to support text in the form of dynamic analogies packaged in a video analogy. The method used in this study was pre-experiment with a one group pretest-posttest design. The research subjects were 40 students from one high school in West Java Province. The data collection instrument used in this research was the conceptual understanding test related to the concept of heat transfer. The results showed that the use of AS-SEText could facilitate more than $70 \%$ of senior high school students to achieve an understanding of the concept of conduction, convection and radiation at the sound understanding level. These results indicate that the use of analogy supported scientific explanatory text has a high effectiveness in facilitating senior high school students to achieve sound understanding levels related to concept of heat transfer. There is no gender bias in achieving a level of sound understanding through the implementation of AS-SEText in heat transfer concept.
\end{abstract}

Keywords: Dynamic Analogy, Level of Conceptual Understanding, High School Students, Heat Transfer Concept.

\section{Introduction}

Understanding the concept is one of the learning outcomes that must be achieved properly by high school students. Understanding the concept of physics in sound will be a very valuable basic asset when they solve problems related to concept application. Sound understanding of physics concept is also very useful when they are trying to explain the physical phenomena they observe in their environment. In the high school education curriculum, conceptual understanding is one of the competencies that students must achieve after participating in 
physics learning. Therefore, physics teachers are required to be able to organize lessons that can facilitate the building of conceptual understanding among students.

In the context of instruction, there have been many physics learning models that can be used by high school teachers to build an understanding of the physics concepts. Likewise for observation activities in the laboratory, various designs of practicum activities that are oriented towards building conceptual understanding have been developed. However, various learning models and the design of these practicum activities become less useful when there is a Covid19 pandemic as is currently happening, which requires restrictions on human interactions, including teacher and student interactions in face-to-face interaction.

One alternative that can be used to overcome this problem is to provide learning materials in the form of text that can be used by students when participating in distance learning in their homes. The required text is interactive text. Text is a lingual unit that is provided in writing or orally with a certain organizational structure to express meaning contextually. There are various types of text, including: descriptive text, discussion text, explanatory text, exposition text, narrative text, negotiation text, procedural text and others (KBBI, 2010). One of the texts that can be used to improve students' understanding of the content and various scientific phenomena is the Scientific Explanatory Text or is abbreviated as SEText.

However, the use of text in which it only presents verbal narratives assisted by static images is considered to be of little help in the process of planting physics concepts related to abstract and microscopic physics content. In fact, there are a lot of physics subject matter that high school students have to study with such characteristics. Heat transfer, electricity, gas kinetic theory, are examples of microscopic and abstract subject matter in physics. Pfundt \& Duit (2009) stated that the main difficulties experienced by students in studying electrical and magnetic content in physics learning are caused by the abstract nature, complexity, and microscopic features of the content.

To be able to describe a microscopic phenomenon that is difficult to understand, a representation is needed that can visualize the invisible microscopic phenomena in real terms. One representation that can be used for this purpose is an analogy representation. Harrison and Coll (2008) state that analogy is a process of comparing an object / idea / event with other objects / ideas / events that have similarities. An analogy includes two components, namely analog and target. Analog; is a familiar situation or object; which is used to describe situations or objects that are not familiar or new situations or new objects that are not familiar, which are called targets. Analogy is a mode of representation, which can be used as a communication tool to model microscopic phenomena so that students can easily understand them. Analogy is divided into two types, there is a static analogy which is depicted in a static image, and there is a dynamic analogy, which is visualized in the form of analogy simulation or analogy video. For physical content containing microscopic phenomena, the use of dynamic analogies is more advantageous than the use of static analogies.

For the purpose of building an understanding of microscopic and abstract subject matter, SEText can be innovated by incorporating dynamic visual media features, such as dynamic analogies. When a dynamic analogy is included in SETeks as a conceptual aid tool, SEText is now supported by a dynamic analogy. Furthermore, SEText which is supported by this dynamic analogy is called Analogy Supported-Scientific Explanatory Text (AS-SEText).

This paper describes the process and research results related to the implementation of ASSEText in physics learning about Heat Transfer content. The research was conducted to answer the following questions: 1) How is the effectiveness of using AS-SEText in facilitating the achievement of a sound understanding level by high school students regarding the concepts of 
Heat Transfer? 2). Is there a gender bias in achieving a sound understanding level in the implementation of AS-SEText?

\section{Methods}

This study used a pre-experimental method with a one group pretest-posttest design. With this design, at the time before and after giving treatment in the form of AS-SEText implementation, pretest and posttest were carried out on subjects to identify the level of understanding of high school students related to the heat transfer concept. The one group pretest-posttest design is shown in Figure 1.

Table 1. The research design used in the study

\begin{tabular}{ccc}
\hline Pretest & Treatment & Posttest \\
\hline $\mathrm{O}$ & $\mathrm{X}$ & $\mathrm{O}$ \\
\hline
\end{tabular}

Here $\mathrm{O}$ is the level of concept understanding test and $\mathrm{X}$ is the treatment in the form of AS-SEText implementation. The subjects of this study were 40 students ( 24 female and 16 male) from one high school in West Java Province. The data collection instrument used was a test of the level of understanding related to the concepts of convection, conduction and radiation in the essay form.

The level of conceptual understanding reviewed in this study consists of five levels, namely; sound understanding, partial understanding, partial understanding with contain alternative conceptions, alternative conceptions, and do not respond (Kurnaz 2015). To determine the level of conceptual understanding of the students based on the answer data of the concept understanding level test, It was used guidelines as shown in Table 1 and Table 2.

Table 2. Conceptual understanding test scoring rubric for the verbal-type test (Kurnaz, 2015)

\begin{tabular}{|l|c|l|}
\hline $\begin{array}{c}\text { Conceptual Understanding } \\
\text { Level }\end{array}$ & Score & \multicolumn{1}{|c|}{ Criteria } \\
\hline Sound understanding (SU) & 4 & $\begin{array}{l}\text { The response given contains all the } \\
\text { components of the answer that can be accepted } \\
\text { scientifically. }\end{array}$ \\
\hline Partial Understanding (PU) & 3 & $\begin{array}{l}\text { The response given contains only part of the } \\
\text { answer components that can be scientifically } \\
\text { accepted from all the expected answer } \\
\text { components. }\end{array}$ \\
\hline $\begin{array}{l}\text { Partial Understanding with } \\
\text { Alternative Conception (PU- }\end{array}$ & 2 & $\begin{array}{l}\text { The response given contains some components } \\
\text { that are scientifically acceptable, but some } \\
\text { components of the other answers indicate an } \\
\text { alternative conception. }\end{array}$ \\
\hline $\begin{array}{l}\text { Alternative Conception } \\
\text { AC) }\end{array}$ & 1 & $\begin{array}{l}\text { The responses given, all of which cannot be } \\
\text { accepted scientifically, contain answers that do } \\
\text { not make sense or contradict scientific } \\
\text { conceptions. }\end{array}$ \\
\hline
\end{tabular}




\begin{tabular}{|c|c|l|}
\hline $\begin{array}{c}\text { Conceptual Understanding } \\
\text { Level }\end{array}$ & Score & \multicolumn{1}{c|}{ Criteria } \\
\hline No Respond (NR) & 0 & $\begin{array}{l}\text { No response, irrelevant response, or unclear } \\
\text { response. }\end{array}$ \\
\hline
\end{tabular}

Table 3. Conceptual understanding test scoring rubric for the picture-type test (Abraham et al.,1992) dan Sağlam Arslan, 2010)

\begin{tabular}{|l|c|l|}
\hline $\begin{array}{c}\text { Conceptual Understanding } \\
\text { Level }\end{array}$ & Scores & \multicolumn{1}{c|}{ Criteria } \\
\hline Sound understanding (SU) & 4 & $\begin{array}{l}\text { The depicted image reflects all scientifically } \\
\text { acceptable components. }\end{array}$ \\
\hline Partial Understanding (PU) & 3 & $\begin{array}{l}\text { The depicted image reflects only a few } \\
\text { scientifically acceptable components. }\end{array}$ \\
\hline $\begin{array}{l}\text { Partial Understanding with } \\
\text { Alternative Conception (PU- } \\
\text { AC) }\end{array}$ & 2 & $\begin{array}{l}\text { The picture depicted reflects some scientific } \\
\text { components but some parts contain } \\
\text { unscientific depictions. }\end{array}$ \\
\hline $\begin{array}{l}\text { Alternative Conception } \\
\text { (AC) }\end{array}$ & 1 & $\begin{array}{l}\text { The picture depicted reflects the whole section } \\
\text { contrary to scientific conceptions. }\end{array}$ \\
\hline No Respond (NR) & 0 & Blank (not drawing). \\
\hline
\end{tabular}

AS-SEText used as treatment in this experimental study consisted of three main parts, namely: part 1, the text of presenting scientific phenomena related to concepts; section 2, scientific explanatory text, and part 3, concluding text. AS-SEText is written in macromedia flash format, so it can be supported by dynamic visual media features such as dynamic analogy video. An example of a dynamic analogy video used to support part 2 of the AS-SEText, namely the scientific explanation text is shown in Figure 2.

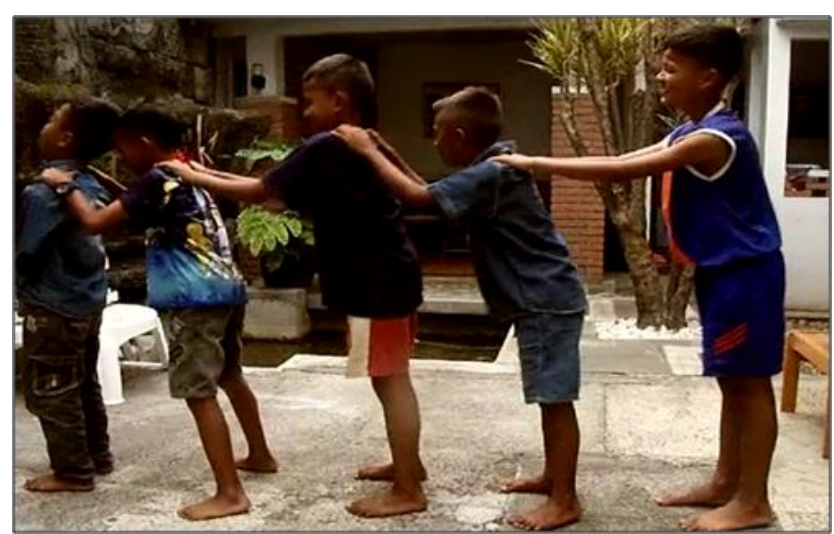

Figure 1. An example of analogy video used to support part 2 of AS-SEText related to the concept of conduction 


\section{Results and Discussion}

\subsection{Results}

Table 4 shows the number of male and female students at each level of understanding related to the concept of conduction before and after the implementation of AS-SEText.

Table 4. The number of students at each level of understanding related to concept of conduction at the time before and after the implementation of AS-SEText.

\begin{tabular}{|c|c|c|c|c|c|c|c|c|c|}
\hline \multicolumn{5}{|c|}{ Before implementation of AS-SEText } & \multicolumn{5}{|c|}{ After Implementation of AS-SEText } \\
\hline \multirow{2}{*}{$\begin{array}{l}\text { Level of } \\
\text { Understand } \\
\text { ing }\end{array}$} & \multicolumn{2}{|c|}{$\begin{array}{l}\text { Number of } \\
\text { students }\end{array}$} & \multicolumn{2}{|c|}{ Percent $(\%)$} & \multirow{2}{*}{$\begin{array}{c}\text { Level of } \\
\text { Understanding }\end{array}$} & \multicolumn{2}{|c|}{$\begin{array}{l}\text { Number of } \\
\text { Students }\end{array}$} & \multicolumn{2}{|c|}{ Percent $(\%)$} \\
\hline & $\mathrm{F}$ & M & $\mathrm{F}$ & M & & $\mathrm{F}$ & M & $\mathrm{F}$ & M \\
\hline SU & 0 & 0 & 0 & 0 & SU & 18 & 13 & 75,0 & 81,0 \\
\hline PU & 8 & 6 & 33,0 & 37,0 & PU & 3 & 2 & 13,0 & 13,0 \\
\hline PU-AC & 5 & 3 & 21,0 & 19,0 & PU-AC & 2 & 0 & 8,0 & 0,0 \\
\hline $\mathrm{AC}$ & 5 & 4 & 21,0 & 25,0 & $\mathrm{AC}$ & 0 & 1 & 0,0 & 6,0 \\
\hline NR & 6 & 3 & 25,0 & 19,0 & NR & 1 & 0 & 4,0 & 0,0 \\
\hline Total & 24 & 16 & 100,0 & 100,0 & Total & 24 & 16 & 100 & 100 \\
\hline
\end{tabular}

Based on the data in Table 3, it can be seen that there is an increase in the level of conceptual understanding among male and female students between before and after the implementation of AS-SEText. The number of female students who reached the sound understanding level was $75.0 \%$ while the number of male students who reached the sound understanding level was $81.0 \%$. It appears that the percentage of female and male students who reach the level of sound understanding related to the concept of conduction is almost the same. Table 5 shows the number of male and female students at each level of understanding related to the concept of convection before and after the implementation of AS-SEText.

Table 5. The number of students at each level of understanding related to concept of convection at the time before and after the implementation of AS-SEText

\begin{tabular}{|c|c|c|c|c|c|c|c|c|c|}
\hline \multicolumn{5}{|c|}{ Before implementation of AS-SEText } & \multicolumn{5}{|c|}{ After Implementation of AS-SEText } \\
\hline \multirow[t]{2}{*}{$\begin{array}{c}\text { Level of } \\
\text { Understanding }\end{array}$} & \multicolumn{2}{|c|}{$\begin{array}{l}\text { Number of } \\
\text { students }\end{array}$} & \multicolumn{2}{|c|}{$\begin{array}{c}\text { Level of } \\
\text { Understanding }\end{array}$} & \multirow[t]{2}{*}{$\begin{array}{l}\text { Number of } \\
\text { students }\end{array}$} & \multicolumn{2}{|c|}{$\begin{array}{c}\text { Level of } \\
\text { Understanding }\end{array}$} & \multicolumn{2}{|c|}{$\begin{array}{l}\text { Number of } \\
\text { students }\end{array}$} \\
\hline & $\mathbf{F}$ & $\mathbf{M}$ & $\mathbf{F}$ & $\mathbf{M}$ & & $\mathbf{F}$ & M & $\mathbf{F}$ & M \\
\hline SU & 0 & 0 & 0 & 0 & SU & 19 & 12 & 79,0 & 75,0 \\
\hline PU & 9 & 6 & 37,0 & 37,0 & PU & 3 & 3 & 13,0 & 19,0 \\
\hline PU-AC & 4 & 4 & 17,0 & 25,0 & PU-AC & 1 & 0 & 4,0 & 0,0 \\
\hline $\mathrm{AC}$ & 6 & 4 & 25,0 & 25,0 & $\mathrm{AC}$ & 0 & 1 & 0,0 & 6,0 \\
\hline NR & 5 & 2 & 21,0 & 13,0 & NR & 1 & 0 & 4,0 & 0,0 \\
\hline Total & 24 & 16 & 100,0 & 100,0 & Total & 24 & 16 & 100 & 100 \\
\hline
\end{tabular}


Based on the data in Table 4, it can be seen that there is an increase in the level of conceptual understanding among male and female students between before and after the implementation of AS-SEText. The number of female students who reached the sound understanding level was $79.0 \%$ while the number of male students who reached the sound understanding level was $75.0 \%$. It appears that the percentage of female and male students who reach the level of sound understanding related to the concept of conduction is almost the same too. Table 6 shows the number of male and female students at each level of understanding related to the concept of radiation before and after the implementation of AS-SEText

Table 6. The number of students at each level of understanding related to concept of radiation at the time before and after the implementation of AS-SEText

\begin{tabular}{|c|c|c|c|c|c|c|c|c|c|}
\hline \multicolumn{5}{|c|}{ Before implementation of AS-SEText } & \multicolumn{5}{|c|}{ After Implementation of AS-SEText } \\
\hline \multirow{2}{*}{$\begin{array}{c}\text { Level of } \\
\text { Understandi } \\
\text { ng }\end{array}$} & \multicolumn{2}{|c|}{$\begin{array}{c}\text { Number of } \\
\text { students }\end{array}$} & \multicolumn{2}{|c|}{$\begin{array}{c}\text { Level of } \\
\text { Understanding }\end{array}$} & \multirow[t]{2}{*}{$\begin{array}{c}\text { Number of } \\
\text { students }\end{array}$} & \multicolumn{2}{|c|}{$\begin{array}{c}\text { Level of } \\
\text { Understanding }\end{array}$} & \multicolumn{2}{|c|}{$\begin{array}{c}\text { Number of } \\
\text { students }\end{array}$} \\
\hline & $\mathbf{F}$ & $\mathbf{M}$ & $\mathbf{F}$ & $\mathbf{M}$ & & $\mathbf{F}$ & $\mathbf{M}$ & $\mathbf{F}$ & $\mathbf{M}$ \\
\hline SU & 0 & 0 & 0 & 0 & SU & 20 & 13 & 84,0 & 82,0 \\
\hline PU & 7 & 5 & 29,0 & 31,0 & $\mathrm{PU}$ & 2 & 1 & 8,0 & 6,0 \\
\hline PU-AC & 6 & 5 & 25,0 & 31,0 & PU-AC & 1 & 1 & 4,0 & 6,0 \\
\hline $\mathrm{AC}$ & 6 & 4 & 25,0 & 25,0 & $\mathrm{AC}$ & 0 & 1 & 0,0 & 6,0 \\
\hline NR & 5 & 2 & 21,0 & 13,0 & NR & 1 & 0 & 4,0 & 0,0 \\
\hline Total & 24 & 16 & 100,0 & 100,0 & Total & 24 & 16 & 100 & 100 \\
\hline
\end{tabular}

Based on the data in Table 4, it can be seen that there is an increase in the level of conceptual understanding among male and female students between before and after the implementation of AS-SEText. The number of female students who reached the sound understanding level was $84.0 \%$ while the number of male students who reached the sound understanding level was $82.0 \%$. It appears that the percentage of female and male students who reach the level of sound understanding related to the concept of conduction is almost the same too.

From Table 4 to Table 6, it can be seen that the number of male and female students who reach sound understanding level related to the three concepts of heat transfer is almost the same. This result is confirmed by the difference test between the two mean scores of the conceptual understanding test related to the concept of heat transfer achieved by female students and male students using the Mann-Whitney statistical test at the level of confidence $(\alpha=0.05)$, as shown in the table. 7 .

Table 7. Results of the difference test of the average score of theconceptual understanding test related of the concept of heat transfer test scores achieved female and male.

\begin{tabular}{|l|c|c|c|}
\hline \multicolumn{1}{|c|}{ Levels of Sound Understanding } & $\begin{array}{c}\text { Mann- } \\
\text { Whitney U }\end{array}$ & $\begin{array}{c}\text { Asymp. } \\
\text { Sig. }\end{array}$ & Conclusion \\
\hline Concept of Conduction & 0.684 & 0.14 & Not significantly different \\
\hline Concept of Convection & 0,464 & 0,08 & Not significantly different \\
\hline Concept of Radiation & 0,548 & 0,11 & Not significantly different \\
\hline
\end{tabular}


In Table 7, it can be seen that the asymp. Sig value obtained from the Mann-Whitney statistical test for all three concepts is greater than the appointed confidence level $(\alpha=0.05)$. This shows that there is no significant difference in the mean score of the conceptual understanding test of conduction, convection and radiation achieved by male and female students. These results indicate that there is no gender bias in achieving the level of sound understanding through the implementation of AS-SEText related to the concept of conduction, convection and radiation.

The results of data processing and analysis show that the use of AS-SEText in learning the concept of heat transfer at the high school level has high effectiveness in facilitating the achievement of sound understanding levels by students. This is shown by the percentage of the number of students who reached the sound understanding level of the three heat transfer concepts, all above $70 \%$. These results indicate the good potential of using text as an alternative mode of learning physics at the high school level during the Covid-19 pandemic, where there are restrictions on direct interaction between teachers and students. Several previous researchers who have examined the effectiveness of using text mode in physics learning both for the purposes of building conceptual understanding and for remediation of misconceptions, include: Suhandi et al (2020), Sahin et al (2010), Yumusak et al (2015), and Ozkan \& Selcuk (2015).

The good potential of using AS-SEText in facilitating the achievement of a sound understanding level is supported by the presence of a dynamic analogy presented in part 2 of the AS-SEText, which is part of the scientific explanation of the natural phenomena being reviewed. The presence of dynamic analogies in the text can help visualize microscopic phenomena that cannot be observed (abstract) into observable phenomena, so that it will be easier for students to understand.

The results of previous research show that when analogies are used systematically in science learning which contains abstract phenomena, students' understanding will increase (Dilber \& Duzgun, 2008). The results of this study are also in line with the results of research obtained by Harrison (1993) who reported that some abstract concepts in science such as pressure, electric current, atomic structure and others can only be taught adequately by using analogy. Being a conception technique, analogy plays an important role in strengthening students' understanding of concepts in a meaningful way and learning in science education (Aykutlu \& Şen, 2011; Gentner \& Smith, 2012). Analogy is often used to make abstract scientific concepts more understandable to students (Chiu \& Lin, 2005). Because analogy is a way of matching newly learned knowledge with those already in students' long-term memory (Karadoğu, 2007).

The use of analogy will improve students' conceptual understanding (Dilber \& Duzgun, 2008). For example, it was reported that when analogies were used in teaching scientific concepts such as electricity (Dilber \& Duzgun, 2008), pressure (Demirci Güler, 2007; Wong, 1993), and heat conduction and wave properties of light (Harrison \& Treagust, 1993), positive changes occur in the achievement of learning outcomes as well as increased understanding of concepts and improvement of their attitudes towards scientific concepts.

The results of the research on the implementation of AS-SEText in Physics learning subject matter heat transfer did not produce gender bias. The implication is that AS-SEText is suitable to be applied to high school students in Indonesia where in the class it does not separate female students and male students, but is united into one study group. Although according to Ali (2019) that in achieving competency in learning outcomes, gender may or may not be influential, but in terms of cognitive learning outcomes, especially regarding conceptions and conceptual understanding, many researchers show that gender does not have a significant effect, thus either. Female students and male students have equal opportunities to achieve scientific conception and 
sound understanding level. Research conducted by Saleh and Mazlan (2019) shows that gender has no effect on the achievement of conceptual understanding by students. In line with that, the results of research conducted by Odelphus and Omeodu (2016) also show that there is no gender bias in achieving the level of sound understanding among students in learning physics. Other researchers who also obtained similar results in their research include: Ogunleye and Babajide (2011), Ivowi (1983), Inyang and Jegede (1991), Hyde and Linn (1988) that gender has no significant effect on achievement scientific conception and sound understanding level by students.

\section{Conclusion}

Based on the results of data analysis, it can be concluded that the implementation of ASSEText written in macromedia flash format has high effectiveness in facilitating the achievement of the level of sound understanding by high school students regarding the concept of heat transfer. There is no gender bias in achieving a level of sound understanding through the implementation of AS-SEText.

Acknowledgments. The author would like to thank the Muhammadiyah University of Purworejo, The Chancellor who has facilitated the research process and also the lecturer who facilitated the publication of my articles at the conference. Hopefully this article will be of use to all of the following researchers.

\section{Reference}

[1] Abraham, M. R., Grybowski, E. B., Renner, J. W., \& Marek, E. A. (1992). Understandings and Misunderstandings of 8Th Graders of 5 Chemistry Concepts Found in Textbooks. Journal of Research in Science Teaching, 29(2), 105-120.

[2] Adolphus, T., \& Omeodu, D. (2016). Effects of gender and collaborative learning approach on students' conceptual understanding of electromagnetic induction. Journal of Curriculum and Teaching, 5(1), 78-86. https://doi.org/10.5430/jct.v5n1p78

[3] Ali, M. (2019). Analisis miskonsepsi siswa berdasarkan gender dalam pembelajaran fisika dengan menggunakan tes diagnostik two-tier di kotabaru. Cendekia: Jurnal Ilmiah Pendidikan, 7(1), 5966. https://doi.org/10.33659/cip.v7i1.120

[4] Aykutlu, I., \& Sen, A. I. (2011). Using Analogies in Determining and Overcoming High School Students ' Misconceptions about Electric Current. Science and Mathematics Education, 5(2), 221 251.

[5] Chiu, M. H., \& Lin, J. W. (2005). Promoting fourth graders' conceptual change of their understanding of electric current via multiple analogies. Journal of Research in Science Teaching, 42(4), 429-464. https://doi.org/10.1002/tea.20062

[6] Dilber, R., \& Duzgun, B. (2008). Effectiveness of analogy on students' success and elimination of misconceptions. Latin-American Journal of Physics Education, 2(3), 3.

[7] Gentner, D., \& Smith, L. (2012). Analogical Reasoning. In Encyclopedia of Human Behavior: Second Edition (2nd ed., Vol. 1). https://doi.org/10.1016/B978-0-12-375000-6.00022-7

[8] Harrison, A. G., \& Treagust, D. F. (1993). Teaching with analogies: A case study in grade-10 optics. Journal of Research in Science Teaching, 30(10), 1291-1307. https://doi.org/10.1002/tea.3660301010 
[9] Harrison, A. G. (1993). A review of textbook analogies for the refraction of light: Proceedings of 18th annual conference of the Western Australian science education association. Perth Western Australia (20-28).

[10] Harrison, A. G., \& Coll, R. K. (2008). Using analogies in middle and secondary science classrooms: The FAR guide - an interesting way to teach with analogies. Thousand Oaks, CA: Corwin Press.

[11] Hyde, J. S., \& Linn, M. C. (1988). Gender Differences in Verbal Ability: A Meta-Analysis. Psychological Bulletin, 104(1), 53-69. https://doi.org/10.1037/0033-2909.104.1.53

[12] Inyang, N., \& Jagede, O. (1991). Development, validation and standardization of Integrated science achievement test for Junior secondary schools. Journal of Science Teachers Association of Nigeria, 27(1), 21-29.

[13] Ivowi, U. M. O. (1983). Achievement level in understanding physics concepts in secondary schools. JOSLC, 1(20), 23-34.

[14] Jian-hua, S., \& Hong, L. (2012). Explore the effective use of multimedia technology in college physics teaching. Energy Procedia, 17, 1897-1900. https://doi.org/10.1016/j.egypro.2012.02.329

[15] Kamus Besar Bahasa Indonesia 2012-2015. "Arti Kata Teks", (Online), (Kamus Besar Bahasa Indonesia (KBBI) Online - arti kata teks, diakses 8 September 2020 pukul 14.40)

[16] Karadoğu, Z. (2007). The Effect of Using Analogy in Primary School Science and Technology Lesson on Success and Attitude. Yüzüncü Yıl University.

[17] Kurnaz, M. A., \& Eksi, C. (2015). An analysis of high school students' mental models of solid friction in physics. Kuram ve Uygulamada Egitim Bilimleri, 15(3), 787-795. https://doi.org/10.12738/estp.2015.3.2526

[18] Ogunleye, B. O., \& Babajide, V. (2011). Commitment to Science and Gender as Determinants of Students Achievement and Practical Skills in Physics. Journal of the Science Teachers Association of Nigeria, 46(1), 125-135.

[19] Ozkan, G., \& Selcuk, G. S. (2015). Effect of Technology Enhanced Conceptual Change Texts on Students' Understanding of Buoyant Force. Universal Journal of Educational Research, 3(12), 981-988. https://doi.org/10.13189/ujer.2015.031205

[20] Pfundt, H., \& Duit, R. (1991). Bibliography: students' alternative frameworks and science education. University of Kiel Institut for Science Education.

[21] Saglam-arslan, A., \& Devecioglu, Y. (2010). Student teachers' levels of understanding and model of understanding about Newton's laws of motion. Asia-Pacific Forum on Science Learning and Teaching, 11(1), 1-20.

[22] Şahin, Ç., Ipek, H., \& Çepni, S. (2010). Computer supported conceptual change text: Fluid

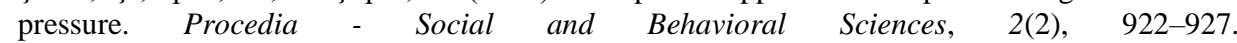
https://doi.org/10.1016/j.sbspro.2010.03.127

[23] Saleh, S., \& Mazlan, A. (2019). The effects of brain-based teaching with i-think maps and brain gym approach towards physics understanding. Jurnal Pendidikan IPA Indonesia, 8(1), 12-21. https://doi.org/10.15294/jpii.v8i1.16022

[24] Suhandi, A., Samsudin, A., Suhendi, E., Hermita, N., Syamsiah, E. N., \& Costu, B. (2020). Facilitating conceptual changes of high school students regarding concepts in static electricity and DC circuits through the use of VMSCDCCText. Universal Journal of Educational Research, 8(3), 815-822. https://doi.org/10.13189/ujer.2020.080312

[25] Wong, E. D. (1993). Self-generated analogies as a tool for constructing and evaluating explanations of scientific phenomena. Journal of Research in Science Teaching, 30(4), 367-380. https://doi.org/10.1002/tea.3660300405

[26] Yumuşak, A., Maraş, I., \& Şahin, M. (2015). Effects of computer-assisted instruction with conceptual change texts on removing the misconceptions of radioactivity. Journal for the Education of Gifted Young, 3(2), 23-50. 